\title{
Study on Chemistry Learning Quality Assurance
}

\author{
(A Case Study in SMAN 4 Palu)
}

\author{
Abdul Gani \\ LPMP \\ Palu, Indonesia \\ ganiabdul13@yahoo.co.id \\ Daud. K. Walanda
UniversitasTadulako
Palu, Indonesia
walanda@gmail.com
}

\author{
Ratman \\ UniversitasTadulako \\ Palu, Indonesia \\ ratmanut@gmail.com \\ Eska Perdanawati Kahar Putri \\ UniversitasTadulako \\ Palu, Indonesia \\ eskakputri@gmail.com
}

\begin{abstract}
SMA Negeri 4 Palu had been targeted as a mentoring model school of education by Quality Assurance Agency Palu in 2016. How to implement a national quality assurance standards of education, especially the content standards, processes, and assessment of competence of graduates in chemistry learning? So we tried to do research with title Study Implementation of quality assurance chemistry teacher coaching. This study aims to find the problem and a description of the chemistry learning system that carried out through the mapping, planning, monitoring, and evaluation as well as the establishment of new standards. Which include analyze the internal and external. This research was descriptive qualitative. Data were collected through questionnaires, interviews, documentation, and triangulation (combined). By three stages, namely, a qualitative descriptive analysis, analysis factor strategic internal and external (IFASEFAS) and formulating strategies with the SWOT matrix. The results showed the problems with the standard document analysis, software development and implementation of the development of chemical continuous learning and the effectiveness of the quality assurance unit. The external strategic factors have a greater potential for the internal strategic factor. Based on the SWOT analysis, the strategy is to increase awareness about the importance of quality assurance in chemistry learning. raise awareness about the importance of quality assurance unit is affected, workshops improving the competence of teachers of chemistry in terms of analyzing the standard document, implement, device development and implementation of learning chemistry carried out continuously. The external exploits opportunities by empowering committees, local communities, and relevant agencies for the success of the school program. Encouraging schools do matriculation of basic knowledge for new students.
\end{abstract}

Keywords: Chemistry Learning, Quality Assurance

\section{INTRODUCTION}

School (SMA) State 4 Palu is one of the schools in Central Sulawesi, which was subjected to a model school in 2016. The results of EDS SMAN 4 Palu 2016 showed that educators and educational staff in terms of number and qualifications are in accordance with the standards. There are 85 foreign teachers and 8 teachers honor all of them meet the standards quality.Ada 14 administrative staff members, 1 library personnel, and 4 caretakers. The number of students in 2016 was 1158 people. The number of students who can think critically, logically, creative and innovative is 463 students (40\%). The number of students who are able to make a report with a description of a sustainable and understood is 463 young people (40\%). The number of students who dared to express opinions new 116 $(10 \%)$. There were $232(20 \%)$ diligently to the library. The number of students per class varies 32-35 people. Teacher handbooks and student books are still lacking and incomplete science laboratories and many substances that are broke

SMAN 4 is one of the schools in Palu which has a land area over four hectares. The number of students in 2015 there were 1187 people, in 2016 there were 1162 people and in 2017 there were 1158 people. SMAN 4 Palu has occupied Mosque prayer 5 times a day with the surrounding community. Support the local community is very nice. Some of the students came from distant districts have even come from neighboring districts namely Donggala and Sigi so it cannot be denied is often no one came too late. Various extracurricular activities undertaken include Scout, the Indonesian Red Cross, School Health Unit, School Safety Patrol and Studio Art Theater. SMAN 4 have a duty and responsibility to fulfill its obligations in providing the quality of education and learning. SMAN 4 Palu aside as model schools as well as the secretariat of the School Principals' Working Group (MKKS) in Palu. As a model school, SMAN 4 Palu has a responsibility to build four schools in the city of the impact hammer. As the secretariat MKKS SMAN 4, Palu has a responsibility to facilitate competency development activities and solve the problem of principals who faced daily. Predicate owned SMAN 4 Palu making it often there are activities undertaken in Palu city level SMAN 4 Palu.

Learning systems must be managed with good management. A number of facts that occurred in SMAN 4 Palu identify any problems in achieving quality education and learning. Lack of laboratory equipment, the materials are difficult to master students especially this time and not all teachers have trained 
chemistry curriculum in 2013 to make its own problems arising in advancing student achievement. Quality assurance of learning is one important aspect that should be a major concern in achieving the expected quality. Is a quality assurance standardsetting and compliance in accordance with certain criteria. In line with the statement that the assessment of the performance of human resources related to the duties and functions in the implementation of quality assurance. Quality assurance of chemistry learning is directly related to the quality assurance cycle. Quality assurance cycle includes the mapping, planning, implementation, monitoring and evaluation and reflection and the establishment of new standards.Mapping is a real and concrete against some sections for the younger to understand and use.

Mapping study is an attempt to further examine documents related to several interrelated and needed to plan to learn [2]. The document is the content standards, competency standards, assessment standards and process standards. There are two indicators to be achieved by this activity is to collect the document content standards, process standards, competency standards, assessment standards, lesson plan preparation guide and analyze the document documents [3].

Planning is an effort to optimize resources in order to produce a more optimal impact [4]. Planning is the crucial early stages of doing things. Plans were made based on the results of the mapping. There are four indicators in this study to be achieved, namely the preparation of the annual program, the preparation of the semester program, syllabus and lesson plan preparation. Implementation of learning requires high-level thinking skills [5]. Implementation of learning is an activity to realize what was planned. There are four components that are planned. The four components must be implemented on schedule and stages in the component. On this occasion will be discussed the only appropriate implementation of learning that has been planned in the lesson plan. There are three indicators that should be implemented in this cycle, namely the implementation of preliminary activities, the implementation of the core activities, and the implementation of activities covers. Monitoring is the activity of control activities is underway and evaluation activities completed job [6]. There are two indicators in this cycle to be achieved by monitoring and evaluation. In line with the opinions [4] that teachers need to reflect continuous learning as part of the quality assurance of learning reflection and the establishment of new standards.

There are two indicators of this cycle is to do the repair and improvement of the learning device learning implementation. Fulfillment of the first indicator, if: preparing a syllabus with as add new standards, preparing lesson plans by adding new standards, develop assessment tools by adding new standards, compiling teaching materials by adding new standard. Indicator two if: improve learning introduction based on the input of students, enriching examples of contextual learning and improvement continuous learning.

\section{METHODS}

The research is a qualitative descriptive. SMAN 4 Palu is set as the object, so this research is a case study. This study was conducted from March 2016 until April 2016. Sumber data consists of primary data and secondary data. The primary data obtained through observation, interviews, and questionnaires. Secondary data such as documents internal data such as data SMAN 4 Palu EDS, and student academic data, documents, quality assurance programs and the results of evaluation of learning activities and supervision carried out by the quality assurance unit.

Selection of respondents to the primary data is purposive sampling, as delivered [1] that the determination of the source of data on the qualitative research is purposive, which is determined by adjusting the purposes of research or a particular purpose. Source to be interviewed in person are those who have the knowledge, experience, and be directly involved in the activities of SMAN 4 Palu learning system that is the principal, vice principal, homeroom and six chemistry teachers. Methods of data collection in this research is observation, interviews, documentation, and triangulation (combined).

Qualitative data analysis using interactive methods as which consists of three flows of activities: data reduction, data presentation, and conclusion/verification. Qualitative analysis conducted quantitative data through the scoring and weighting. This study uses a total weight of 100. Strength rating for Variable Value rated 1 to 4 . Given a value of 1 if the possibility of its performance indicators is declining compared to major competitors. Rated 2 if the indicator's performance is the same as the main contenders. While rated 3 or 4 , if the proficiency level indicator is better than major competitors. The higher the value of the indicator means that next year's performance will be better than its main competitors. Rating the value of variable weakness rated 1 to 4 . Given a value of 1 if the indicators are more weaknesses than its main competitors. Instead rated 4 if the weakness of these indicators decreased compared to major competitors in the next year. Score value obtained based on the value of the weight multiplied by the value of rating. Step of processing and data analysis in this research done in three stages, namely: (1) descriptive and qualitative analysis, (2) analysis of IFAS-EFAS, and (3) the formulation of a strategy with SWOT matrix.

The data has been obtained and analyzed using IFAS matrix. Further analysis was conducted on external factors of the learning system to get EFAS. The analysis will be combined to further define alternative strategies that can be offered and include it in the SWOT matrix.

\section{RESULTS AND DISCUSSION}

The study chemistry teacher data obtained documentation that is: there are six teachers who taught chemistry at SMAN 4 Palu. One-person qualified strata two and five qualified undergraduates. Two people have experience in teaching 20 years and over, two people have the teaching experience of 10 years upwards and two people have the experience of teaching under 10 years old. Four people chemistry teacher explain difficult material followed by students is a matter of calculation, one person explained elusive material that students are electrochemical and one more person say that the material is difficult to understand students' material molecular orbital theory. [5] explains that the level of difficulty of the material can be approximated by the teaching strategies are fun, challenging and stimulating and train students to think critically. 
The result of data reduction, interviews and document research and triangulation of data on the study of chemistry learning quality assurance to 6 chemistry teacher obtained the information (1) Component mapping. The average value of 100 on the indicator standard documents. The average value of $60 \%$ on the standard document analysis: (2) The planning component value is an average of 100 on the preparation of program an average of 100 on the preparation of the semester program. The average value of $80 \%$ in the preparation of the syllabus. The average value of 70 in the preparation of the RPP. (3) The components of the implementation. The average value of 90 on the preliminary activities. The average value of 70 on core activities. The average value of 80 in the closing activity. (4) Component Monitoring and Evaluation. The mean value of $60 \%$ on the implementation of monitoring. The average value of 60 on the implementation of the evaluation. (5) Components reflection / new standard. The average value of $50 \%$ on the development of continuous learning device. The average value of $50 \%$ on the development of the implementation of continuous learning. The results of this analysis are determined by internal and external factors. Internal factors include the strengths and weaknesses possessed by chemistry teachers and schools.

The strength of the annual program is complete, a full semester program, complete a standard document, the document is complete and activity RPP preliminary nice learning. The weaknesses of the development of chemical learning device are not maximized, monitoring and evaluation have not been going good, yet the quality assurance unit and the development of chemical learning implementation is not maximized. Threats owned: school location close to the market, $30 \%$ of parents is a poor category, the diversity of the student intake, the competition between educational institutions and the influence of technological developments. Opportunities: strong committee support, strong community support, strong support of other stakeholders, a strong belief provincial agencies and other good cooperation of institution. Indicators any internal and external components further analyzed in the SWOT analysis to calculate a score and rating for each indicator.

TABLE 1. RESULtS OF MATRIX IFAS

\begin{tabular}{|l|c|c|c|}
\hline Internal Strategic Factors & Rating & Weight & Score \\
\hline Strong & & & \\
A. Authors annual program & 3 & 5,0 & 15,0 \\
B. Documentation standards & 3 & 5,0 & 15,0 \\
C. Preparation of the semester program & 4 & 15,0 & 60,0 \\
D. Preparation implementation of learning & 2 & 10,0 & 20,0 \\
E. Activity learning introduction & 2 & 5,0 & 10,0 \\
Total of Strong & & $\mathbf{4 0 , 0}$ & $\mathbf{1 2 0 , 0}$ \\
Weakness & 2 & 15,0 & 30,0 \\
A. The development of learning tools & 1 & 15,0 & 15,0 \\
B. Monitoring and Evaluation & 1 & 15,0 & 15,0 \\
C. The quality assurance unit & 1 & 5,0 & 5,0 \\
D. Development of the implementation of & 3 & 10,0 & 30,0 \\
learning & & $\mathbf{6 0 , 0}$ & $\mathbf{9 5 , 0}$ \\
E. Analysis curriculum documents & & & \\
Total of weakness & & $\mathbf{1 0 0 , 0}$ & $\mathbf{2 1 5 , 0}$ \\
\hline Total of internal &
\end{tabular}

The end result of the calculation of the weight and rating each factor using IFAS matrix shows that the indicator preparation semester program has the highest score compared to the other (60.0), followed by the preparation of the competence of learning tools and document chemical standards and annual programs. The lowest score is owned by preliminary indicators of learning activities. The results of the analysis of the weaknesses of the quality assurance IFAS chemical study shows that there are deficiencies in the quality assurance system of learning chemistry is the development of learning tools (30.0) and analysis of curriculum documents (30.0), followed by the quality assurance unit and the development of each chemical learning implementation respective values (15). Indicators learning device that still needs to be developed is the indicator of achievement of competence and the formulation of the test assembly. Development of chemical learning device must be carried out continuously in order to obtain appropriate educational quality expectations of the customer [7]. Indicators Analysis standard document that still needs to be improved is to analyze the relationship between the core competence with basic competence. Analyzing linkages basic competency models and learning strategies that will be used as described by [8]. Analysis standard document is also intended to ensure the quality of learning tools that will be made as described by [9] The results of analysis of this document will also be the standard linkage mapping data processes, content standards, competency standards and assessment standards. This is consistent with the opinion [10] that one of the implementations of quality assurance of learning is the standard analysis of data that will be used in the planning of learning.

Monitoring and evaluation indicators that still need to be improved are the teachers familiarize themselves reflection after teaching is completed. Indicators of the quality assurance unit that still needs to be improved are to start the organization, competency management, and infrastructure needs. Indicators implementation of learning that still needs to be improved is the core activity of students learning in line with expectations. Core activities of learning is an activity that determines transfer knowledge, attitudes, and skills [11]. These activities should make the students as the main customers enjoying and savoring each learning activity. These activities must be designed with the methods, approaches, and models that fit the needs of students. The material is difficult to understand the student should be reviewed in advance by some teacher friends. Preferred methods and models in the learning plan should be understood Retained Earnings in accordance with the opinion of passage and syntax that transfer knowledge, attitudes, and skills to young students realized.

Each material must be presented in accordance with the level of students' thinking skills explains that one of the critical success of learning activities is a fun learning environment. Needs to be organized and the learning environment is designed according to the wishes of citizens learned so not boring and can increase the child creativity. Creativity can be enhanced with a young child when learning that teachers' members opportunities for students to get more involved in learning. The scientific approach is a major learning approach in teaching the curriculum in 2013, therefore, every teacher should be able to apply the scientific approach to learning. The scientific approach can guide students to think critically, creatively, communicative and collaborative [8]. 
TABLE II. RESULTS OF MATRIX EFAS

\begin{tabular}{|l|c|c|c|}
\hline External Strategic Factors & Rating & Bobot & Scor \\
\hline Opportunities & & & \\
A. Support the school committee & 4 & 15,0 & 60,0 \\
B. Support local communities & 4 & 15,0 & 60,0 \\
C. Support other stakeholders & 2 & 5,0 & 10,0 \\
D. Confidence provincial offices to & & & \\
schools & 3 & 15,0 & 45,0 \\
E. Cooperation with other agencies & 3 & 5,0 & 15,0 \\
Total of opportunities & & $\mathbf{5 5 , 0}$ & $\mathbf{1 9 0 , 0}$ \\
& & & \\
Threats & 1 & 5,0 & 5,0 \\
A. School location close to the & 2 & 5,0 & 10,0 \\
market & 3 & 15,0 & 45,0 \\
B. 362 parents (30\%) of low-income & 1 & 5,0 & 5,0 \\
C. Diversity of student intake & & & \\
D. The competition between & 3 & 15,0 & 45,0 \\
educational institutions & & $\mathbf{4 5 , 0}$ & $\mathbf{1 1 0 , 0}$ \\
E. Effect of technological progress & & $\mathbf{1 0 0 , 0}$ & $\mathbf{3 0 0 . 0}$ \\
\hline Total of threats & & & \\
\hline Total of Eksternal & &
\end{tabular}

The results of the calculation of the weight and rating each factor using EFAS matrix shows the opportunities of learning in quality assurance is the most dominant chemistry committee support (60.0) and the support of the community around the school (60.0), followed by support trust the provincial office of the school. The main threat to the quality assurance of learning chemistry is the diversity of the student intake (45.0) and the influence of progress technology. Input students from different socio-cultural backgrounds and varying the internal capacity to make effective quality assurance system must implement a strategy of learning chemistry creative learning and innovative to strengthen the process steps to produce quality outputs and outcome. Indicators threat that must be resolved is the proximity of the school with the advance of the market. A market is the meeting place for buyers and sellers from all walks of life. Mentoring allows an emotional relationship between teachers and students can be harmonized so that the students themselves raised wrongdoing. Students should obtain clarification from all stakeholders to enable students to avoid the spread of the harm goods. The cross-agency role required as communicated by [12]. Another thing you can do is the need for the involvement of associations in supervising student teachers. A teacher who is bound by association when seeing the students violated then there must be an impulse to guide him though not the students who are studying in school (Kadar, Kebumen, and Kebumen, n.d.).

Indicators of low-income parents are one indicator that must be resolved. There should be no reason a student cannot study for economically disadvantaged. At school-based management is one answer for the needs of school-based management education costs and communicated together and solved together. Indicator diversity of student intake can be solved by doing matriculation basic knowledge for new students whose abilities are essentially unfinished. At the time of admission of new students do test the basic ability. New students who have not completed basic mathematical knowledge basically especially given matriculation. it is important to equalize the initial capability younger students to attend classes as described by [7] that the mapping ability of students' initial knowledge of an activity that is critical to successful learning.
Indicators competition between educational institutions could be solved by establishing an intense communication with sesame educational institutions. Applying TQM management could be one solution [4].Continuously also be made to constantly adjust school programs to customer requirements [13]. Indicators should be anticipated effect of technological progress by implementing integrated management [3]. The involvement of teachers' organizations [4]

Based on the results of IFAS and EFAS matrix, can be determined quantitatively chemistry learning quality assurance position on the SWOT matrix is in quadrant I. The calculation is done by finding the difference of each total score weighting to determine the position on the $\mathrm{x}$-axis and $\mathrm{y} \cdot(120-95)=(25)$ and $(190-110)=(80)$. The combination of internal and external strategic factors then formulated into four main types of strategies are divided into twelve alternative strategies of developing quality assurance systems chemistry learning as seen in Table III.

TABLE III. SWOT MATRIX ANALYSIS OF CHEMICAL EDUCATION QUALITY ASSURANCE

\begin{tabular}{|c|c|}
\hline STRATEGI (SO) & STRATEGI (WO) \\
\hline $\begin{array}{l}\text { 1. To improve and develop the } \\
\text { cooperation committee in the } \\
\text { preparation of the annual } \\
\text { program of workshops and } \\
\text { semester } \\
\text { 2. Improve understanding of the } \\
\text { committee and other } \\
\text { stakeholders about the } \\
\text { curriculum standards } \\
\text { document. } \\
\text { Increase the involvement of } \\
\text { other agencies in the } \\
\text { development of learning } \\
\text { activities }\end{array}$ & $\begin{array}{l}\text { 1. } \begin{array}{l}\text { Empower the committee in } \\
\text { monitoring and evaluation of } \\
\text { learning }\end{array} \\
\text { 2. Empower the relevant agencies } \\
\text { (LPMP) and the Department of } \\
\text { Education in carrying out } \\
\text { quality assurance unit } \\
\text { 3. Involve committee and } \\
\text { stakeholders in developing the } \\
\text { implementation of learning and } \\
\text { analytical chemistry } \\
\text { curriculum documents }\end{array}$ \\
\hline STRATEGI (ST) & STRATEGI (WT) \\
\hline $\begin{array}{l}\text { 1. } \begin{array}{l}\text { Preparation of devices to } \\
\text { accommodate learning } \\
\text { character values }\end{array} \\
\text { 2. Accommodate input low- } \\
\text { income parents in the } \\
\text { preparation of the annual } \\
\text { program and the semester } \\
\text { program } \\
\text { 3. Loading program } \\
\text { matriculation basic } \\
\text { capabilities for new students } \\
\text { in the semester program and } \\
\text { RKAS }\end{array}$ & $\begin{array}{l}\text { 1. Raise awareness of all citizens } \\
\text { of the school to better promote } \\
\text { the interests of the school } \\
\text { rather than individual interests } \\
\text { 2. Implementing an effective } \\
\text { management to minimize the } \\
\text { threats and weaknesses in } \\
\text { achieving the objectives of the } \\
\text { school } \\
\text { 3. Build a community of learners }\end{array}$ \\
\hline
\end{tabular}

\section{CONCLUSION}

Issues of quality assurance chemistry learning is on the component analysis mapping standard document is not maximized, the components of quality assurance unit has not gone well, the components of the implementation of the core activities of learning has not been carried out in accordance with the syntax of the model used, the components of the monitoring and evaluation have not done continuously monitoring and evaluation, as well as the reflection component software development, has not done learning and development are 
formulated learning. Strategy implementation internally is to raise awareness about the importance of quality assurance in teaching chemistry to the leadership of the school and socialized to all teachers, especially chemistry teachers workshop. A concrete action is improving the competence of teachers of chemistry in terms of analyzing the standard document developed the chemistry learning and developing learning execution of chemistry. External exploit opportunities by empowering committees, local communities, and relevant agencies to assist schools in the school program a success. School testing the capability of the new students. Schools do matriculation basic capabilities for new students who have a basic ability is low.

\section{ACKNOWLEDGEMENT}

The authors recognize any form of hardship, ease, joy, and sorrow are all that is inherent in every human life. Similarly, in the preparation and writing of this article, the author can overcome thanks to the motivation and support from various parties, especially friends Science Education Doctoral Studies Program which has provided science, guidance, motivation, invaluable advice, as well as the time for the author since the preparation of this article, the authors say many thanks.

\section{REFERENCES}

[1] D. Meirawan, "Penjaminan Mutu Satuan Pendidikan Sebagai," vol. IV, no. 2, pp. 126-137, 2010.

[2] G. E. Jl, J. Sudirman, and S. Jakarta, "Pencapaian Prestasi Belajar Contribution of Eight National Education Standars Towards," vol. 20, pp. 470-482, 2014.
[3] P. Sains, P. Universitas, N. Surabaya, A. Pratama, L. Yuanita, E. Susantini, M. Program, S. Pendidikan, P. Pascasarjana, U. Negeri, D. Pascasarjana, P. Pendidikan, S. Univesrtitas, and N. Surabaya, "Pengembangan perangkat pembelajaran kimia berbasis strategi belajar peta konsep untuk meningkatkan pemahaman konsep dan kemampuan berpikir kritis siswa sma," vol. 5, no. 2, pp. 1023-1031, 2016.

[4] G. K. Akselerasi, "Educational Management," vol. 2, no. 1, 2013.

[5] S. Bailin, "Critical Thinking and Science Education," pp. 361-375, 2002.

[6] L. H. Winingsih, P. P. Kebijakan, G. E. Lantai, J. J. Sudirman, and J. Pusat, "Profesionalisme guru The Role Local Government, LPMP and P4TK In The Improvement of Teacher Professionalism," pp. 579-593, 2013.

[7] S. Lindblom-ylänne, A. Nevgi, S. Lindblom-ylänne, K. Trigwell, and A. Nevgi, "How Approaches to Teaching Are Affected by Discipline and Teaching Context How approaches to teaching are affected by discipline and teaching," no. April 2017, 2006.

[8] B. D. Short, "Teaching Scientific Concepts using a Virtual World Minecraft," pp. 55-58, 2011.

[9] V. Mellado and L. S. Link, "The classroom practice of preservice teachers and their conceptions of teaching and learning science," no. 1990, 1994.

[10] M. Wilson and K. Scalise, "Assessment to improve learning in higher education : The BEAR Assessment System," pp. 635-663, 2006.

[11] C. Sciences, "Pedagogical Knowledge As A Way Forward: Applied Reaschesd In Chemistry Education," vol. 5, no. 3, pp. 215-228, 2004.

[12] D. Mengembangkan, S. Uas, and B. Hots, "Studi Kemampuan Guru Kimia SMA Lulusan UNY dalam Mengembangkan Soal UAS ... ( Dodi Iskandar, Senam ) - 65," vol. 1, no. April 2015, pp. 65-72, 2013.

[13] D. Meningkatkan, M. Pendidikan, D. I. SMP, and C. Garut, "Jurnal Akuntabilitas Manajemen Pendidikan Tersedia Online : http://journal.uny.ac.id/index.php/jamp," vol. 3, no. 1, 2015. 